\title{
Multimode Learning with Higher Order Thinking Skills in Pandemic Covid-19 Era
}

\author{
Yuli Arti $^{1{ }^{1 *}}$ Jaslin Ikhsan ${ }^{2}$ \\ ${ }^{1}$ Master of Natural Science Education, Faculty of Mathematics and Natural Sciences, Universitas Negeri \\ Yogyakarta, Indonesia \\ ${ }^{2}$ Department of Chemistry Education, Faculty of Mathematics and Natural Sciences, Universitas Negeri \\ Yogyakarta, Indonesia \\ *Corresponding author.Email: yuliarti.2018@student.uny.ac.id
}

\begin{abstract}
The study is conducted to know the influence of multimode learning with higher order thinking skills in the pandemic covid-19 era. As we know that the learning system is moved from offline to online learning in the pandemic covid-19 era, every teacher is also required to prepare the online learning. The online learning should be designed without decreasing the students' higher order thinking skills because we have to increase the higher order thinking skills due to the result of PISA 2018 that the science ability is decrease. Thus the learning system is designed with multimode learning because multimode learning is combined more than one learning model so it can improve students' independence. The multimode learning that combined with technology gives the new experiences of the students. This result of this study is analysed with quantitative method by T-Test and N-Gain use SPSS. There is an improvement of higher order thinking skills with multimode learning that and no improvement without multimode learning.
\end{abstract}

Keywords: Multimode learning, Higher order thinking skills, Pandemic covid-19 era.

\section{INTRODUCTION}

Coronavirus diseases (Covid-19) has been occurred the most country in the world since the end of 2019. The first country that infected by that virus is China, especially in Wuhan City. The case of human victim by this virus is increased day by day. Globally, as of 07.30 p.m. CEST, 2 March 2021, there have been 114.140.104 confirmed cases of COVID-19 including 2.535.520 deaths reported by WHO [1]. The case of COVID-19 in Indonesian is shown in Figure 1.

The coronavirus give impact to many life's sector especially the educational sector. In this era, the learning system is totally different from the usual system. The government appeal all the school especially in red zone with distance learning to break the chain of spread of the virus.

The teacher need to improve the learning system and learning method to send the concept mastery to the students. But the real condition is not all the teacher master educational technology, it is evidenced by the result of first study in the month of July 2020 in the sub-urban school in Yogyakarta that show 7 of 13 teacher in that school do not master the education technology. They usually use the common system like google classroom, WhatsApp group and google form.

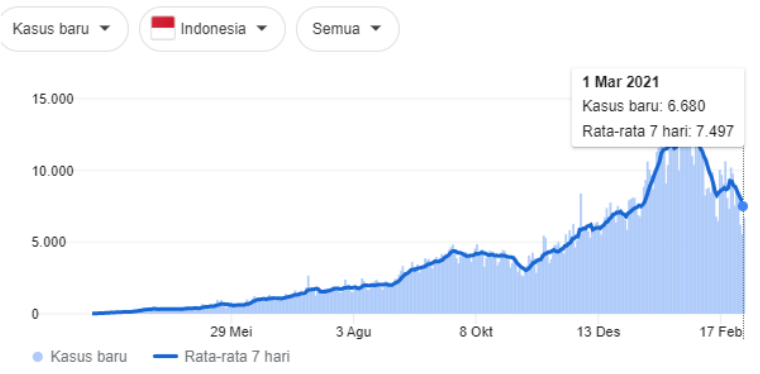

Figure 1. The case of COVID-19 in Indonesian based on Statista 2020. There is a increase if every month.

The continuous use of those technology make the learning system is very monotone so that the students also bored and they prefer not to attend the lessons. Thus making the online learning process not optimal.

If the learning system did not optimal, the 21th century skills of the students will not be increasing. And it is the problem that we face now, even before the pandemic era. It is shown in the result of PISA 2018 by OECD in the science performance is decrease 
from the last period. The result of science performance is 396 decrease form 403 in the year of 2015 [2].

These condition are the background to apply the multimode learning in learning system in the pandemic era. Multimode learning can be a learning method that combines two or more methods and approaches in learning to achieve the objectives of the learning process [3].

It suitable for the science learning because not all the science learning can be done by technology for example the process of the students' observation in real object. So that multimode learning is conducted to maximizing the learning process.

The multimode approach allows the use of more than one learning model in the delivery of a single material. The multimode approach was chosen as the basis for learning system because when integrated with technology it is able to engage students in activities to build individual and collaborative meaning to prepare students to explore knowledge and the outside world through technology by utilizing written, oral, audio, and visual [4].

The concept of higher order thinking (HOT) is derived from the Bloom taxonomy of cognitive domain introduced in 1956 [5]. The cognitive domain involves knowledge and the development of intellectual skills [6].

The multimode learning can be used in learning activity for influencing higher order thinking skills especially in this pandemic era, because it can train students' independence. So, this study is conducted to know the influences between multimode learning with higher order thinking skills in pandemic era. Figure 2 shows the diagram of learning activity as a combination of distance learning and individual observation with the multimode learning.

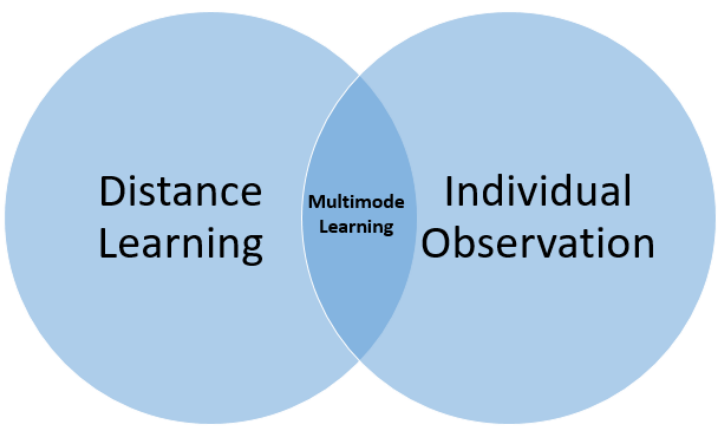

Figure 2 The distance learning is combined with individual observation as a multimode learning

\section{METHOD}

This study is experiment research. The research is carried out in the month of September 2020. It is involved of 40 Junior High School Students in Yogyakarta. The instruments that used in this research are the assessment question with higher order thinking skills aspect that contains cognitive abilities C4-C6 that involved analysing, evaluating, and creating.

The instruments is suitable with the concept of measurement. The questions are analysed with empirical validation to know the validation and reliability. Empirical validation used the QUEST software. The result of empirical validation is reliable (high) with the score of internal consistency 0,61 and all number are valid because they are suitable with Rasch model so the instruments can be used in the research.

The research method is using quasi experiment design. The research begins with a pre test to know the first think abilities of the students, and then the treatments and the last is post test. The group was divided into an experimental class and a control class. The experimental class used multimode learning and the control class used only distance learning. The form of quasi experiment is pre test and post test control group design. The model of experiment design is showed in figure 3 below:

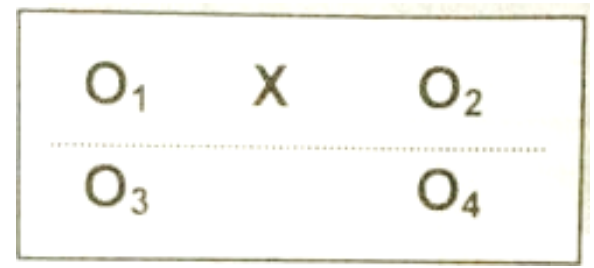

Figure 3 The quasi experiment design

In figure $3, \mathrm{O}_{1}$ as a pre test in experiment group, $\mathrm{O}_{2}$ as a post test in experiment group, $\mathrm{O}_{3}$ as a pre test in control group, $\mathrm{O}_{4}$ as a post test in control group, and $\mathrm{X}$ is the treatment in experiment group use multimode learning.

The data will be analysed by homogenity and normality test as a first requirement. After that, the data will be analyzed with paired t-test by SPSS and $\mathrm{N}$-Gain analysing. The last one is analyzed the description of each higher order thinking skills aspect.

\section{RESULT AND DISCUSSION}

The learning was started with teacher's instruction by distance learning using Google Classroom and WhatsApp Group. The instruction is about how to do the observation in the matter of measurement. The 
students were instructed to measure the things in their home with the measuring instruments like ruler and roll meter.

The students should write the result on the table 1 below:

Table 1. The observation table

\begin{tabular}{|l|l|l|l|}
\hline \multicolumn{1}{|c|}{ The } & $\begin{array}{c}\text { Measure } \\
\text { with } \\
\text { a Ruler }\end{array}$ & $\begin{array}{c}\text { Measure } \\
\text { with } \\
\text { Students' } \\
\text { Span }\end{array}$ & $\begin{array}{c}\text { Measure } \\
\text { with } \\
\text { Parents' } \\
\text { Span }\end{array}$ \\
\hline $\begin{array}{l}\text { The } \\
\text { length of } \\
\text { table }\end{array}$ & & & \\
\hline $\begin{array}{l}\text { The } \\
\text { length of } \\
\text { bed }\end{array}$ & & & \\
\hline $\begin{array}{l}\text { The } \\
\text { length of } \\
\text { book }\end{array}$ & & & \\
\hline $\begin{array}{l}\text { The } \\
\text { length of } \\
\text { cupboard }\end{array}$ & & & \\
\hline
\end{tabular}

The students did the measurement by their self. They measured with ruler as a standard unit. They also measured with their span and their parents' span. Before the activity, they did pre test and after the activity they did post test. The data pre test and post test each class is shown in table 2 below:

Table 2. The data pre test and post test

\begin{tabular}{|l|l|l|l|}
\hline \multicolumn{1}{|c|}{ Group } & Pre Test & \multicolumn{1}{|c|}{$\begin{array}{c}\text { Post } \\
\text { Test }\end{array}$} & \multicolumn{1}{|c|}{ Difference } \\
\hline Experiment & 62.00 & 65.00 & 3.00 \\
\hline Control & 58.00 & 60.00 & 2.00 \\
\hline Difference & 4.00 & 5.00 & \\
\hline
\end{tabular}

The data in each category is homogeneous in each group shown by the significance of KolmogorovSmirnov with the number 0,200 in experiment class and 0,102 in control class in post test data. The significance of Kolmogorov-Smirnov in pre test data in experiment class is 0,200 and control class is 0,222.

The data in each category is also normal in each group shown by the significance of KolmogorovSmirnov with the number 0,200 in pre test and post test in experiment group. The data $\mathrm{n}$ control group is 0,200 and 0,200 . Thus it can be analysed with paired t-test.

The result of paired t-test in experiment group is shown by the significance $0,020<0,05$ so there is an effect multimode learning with higher order thinking skills. In the other hand, the result of paired t-test in control group is shown by the significance $0,421>$ 0,05 that means no effect of higher order thinking skills without multimode learning.

The data also analysed with N-Gain Test to determine the normalized increased between pre test and post test in experiment and control group. The result of $\mathrm{N}$-Gain score is shown in table 3 below.

Table 3. The N-Gain score between experiment and control group

\begin{tabular}{|l|c|c|}
\hline \multicolumn{1}{|c|}{ Group } & N-Gain Score & Category \\
\hline Experiment & 0.07 & Low \\
\hline Control & 0.04 & Low \\
\hline
\end{tabular}

Based on the result of N-Gain Score, the category of two groups are low, but the experiment group's score with 0,07 is higher that control group's score with 0.04 .

The score of each higher order thinking skills aspect is shown in table 4 .

Table 4. The score of each higher order thinking skills aspect

\begin{tabular}{|c|c|c|c|c|}
\hline \multirow{2}{*}{ Aspect } & \multicolumn{2}{|c|}{ Experiment } & \multicolumn{2}{c|}{ Control } \\
\cline { 2 - 5 } & Pre & Post & Pre & Post \\
\hline Analyzing & 65.35 & 69.19 & 57.69 & 63.88 \\
\hline Evaluating & 59.36 & 68.18 & 62.63 & 55.71 \\
\hline Creating & 75.02 & 78.00 & 63.46 & 71.25 \\
\hline
\end{tabular}

The students' activity can increase the students' process skills that can increase the higher order thinking skills. Higher order thinking skills have the relationship with science process skills. The science process skills make the students has a critical thinking skills to analyse the phenomena or the facts. Thus it can increase the higher order thinking skills because the one aspect of the higher order thinking skills is analyse [7].

These activities include observation and measuring activity. It can be done by ICT in learning process. Doing individual practicum use technology or not use technology can assets thinking and science process 
skill test in student assessment and especially by using some scientific approach in learning process like multimode learning [8].

It can be shown in the result of this study that the higher order thinking skills and each aspect is increase. The improvement of each aspect in experiment group is bigger than the control group. It means that multimode learning can improve the aspects of higher order thinking skills. It also shown in the result of paired t-test that there is influence between multimode learning and higher order thinking skills. The relationship between multimode learning and higher order thinking skills is also shown in the N-Gain Score with 0.07 in low category but the experiment group's result is higher than control group result with 0.04 . The $\mathrm{N}$-Gain Scores show the enhancement between class that use multimode learning and the class without multimode learning. The two of them are in low category. The low category is because of some factors such as the students' background previous education and school's input is the low level so this can be the factors that reflects the students' academic performance. The school's input make little different in students learning activity so it has contribution to the students' academic performance [9].

Multimode learning can improve the learning outcomes as higher order thinking skills because it is includes the flexibility, interaction, learning process and learning climate. It is flexible because the students can practice by their self and it need the independence of the students [10].

Multimode learning also need the interaction between students and teacher that can occurred by technology and video conference. It held in this research. The teacher also used google meet as the media of video conference to confirm the materials. It can improve students' higher order thinking skills. Based on the study result, the multimode learning can be implemented to the learning system especially in pandemic era, but it needs some efforts to implement the learning method so that the teacher also need to adjust with the students ability and also control the classroom management as well as possible.

\section{CONCLUSION}

There is an improvement of higher order thinking skills with multimode learning and no improvement without multimode learning.

\section{AUTHORS' CONTRIBUTIONS}

The first author contributes in arrange the structure and method should be used in this research. The first author also contributes as a corresponding author. The second author contributes as a reviewer of the research and give a lot of ideas in the research.

\section{REFERENCES}

[1] WHO, COVID-19 Report . The report of coronavirus case, March 2021. Accessed on: March. 2021. [Online]. Available:https://covid19.who.int/?gclid=Cj0KC Qjw28T8BRDbARIsAEOMBcxEOlvgdZrH15Hlk9 R37TuqXkxpBvkqumk5NDEX1zq s9IRDBzjgQaAsADEALw_wcB

[2] OECD Database, The result of PISA 2018. Accessed on: March.2, 2021. [Online]. Available: https://www.oecd.org/pisa/data/2018database/

[3] D. Hediansah. 2020. Hybrid Learning Development to Improve Teacher Learning Management. JKTP: Jurnal. Kajian Teknologi Pendidikan, 3 (2017) 1-9. https://doi.org/10.17977/um038v3i12019p001

[4] Y. Chen. 2010. Exploring Dialogic Engagement with Readers in Multimodal EFL Textbooks in China. Visual Communication. Jurnal of SAGE 9 (2014) https://doi.org/10.1177/1470357210382186

485-506.

[5] M. Forehand, Bloom's taxonomy, Emerging perspectives on learning, teaching, and technology, March 2010. Accessed on: March.2,2021.[Online]. Available: http://projects.coe.uga.edu/epltt/index.php?title= Bloom\%27s_Taxonomy

[6] B.S. Bloom. Taxonomy of educational objectives, Handbook I: The cognitive domain. NY: McKay, 1956.

[7] B.E. Meyers, Assessing Agriculture Teacher' Capacity for Teaching Science Integrated Process Skills, Journal of Southern Agricultural Education Research 54(1) (2004) 74-84.

[8] A. Masek, Y. Sulaiman, The Effect of Problem Based Learning on Critical Thinking Ability: A Theoretical and Empirical Review. International Review of Social Sciences and Humanities 2(1) (2011) 215-221.

[9] L. Darling, Teacher Quality and Student Achievement: A Review of State Policy Evidence. Journal of Education Policy Analysis 
Archives, Stanford Univerity 8(1) (2000) 1-44.

https://doi.org/10.14507/epaa.v8n1.2000

[10] Z. Chen, Teaching Effect of the Multi-mode Blended Learning Model from Students' Perceptions. Technology in Education. Innovative Solutions and Practices (2018) 188199. DOI: https://doi.org/10.1007/978-981-130008-0_18 